\title{
Penggunaan Bahasa Alay di Ruang Publik
}

\author{
Hesty Kusumawati \\ Sekolah Tinggi Agama Islam Negeri Pamekasan, Indonesia
}

Keywords:

Writing,

Language usage alay, social networking
Kata Kunci:

menulis, bahasa alay, dunia maya

\begin{abstract}
Abstrak: The phenomenon of interesting language in the contemporary context is the emergence of alay language on the writing of SMS sentences or social networking such as facebook. The existence of alay language by teenagers in the virtual world (internet), such as facebook in the form of writing, because the character of alay language is to combine various characters, alphabet numbers, abbreviations and the use of capital letters that are not uniform. This language is considered as a typical expression of media in communicating in cyberspace (internet). Furthermore, how the use of alay language in the public space of facebook. The purpose of this study describes the use of alay language Pamekasan teens on facebook in the context of the use of abbreviations, new words, and foreign vocabulary. The research method using descriptive qualitative because the data collected derived from qualitative data in the form of verbal data instead of numbers, ie follow-up adolescent facebook users who write status and comments. Based on the results of data analysis can be concluded that the use of language alay Pamekasan teenagers on facebook on the use of acts of speech representatives quite a lot, ie on the status or comments written on the facebook wall. This speech acting function tells others about something that has a correspondence between the delivered speech and the reality that lies with the speaker. The use of alay language Pamekasan in facebook on the use of speech acts directive can be seen on the status or comments written in facebook account, that is when the speech on facebook account contains things that are the desire of the speakers to others to do something. The use of Pamekasan alay language language on the use of expressive speech acts can be seen when the status or comments of speakers on the wall facebook contains a statement that describes what speakers feel
\end{abstract}

ABSTRACT

Abstrak: Fenomena bahasa yang menarik dalam konteks kekinian adalah munculnya bahasa alay pada penulisan kalimat SMS atau jejaring sosial seperti facebook. Keberadaan bahasa alay oleh para remaja di dunia maya (internet), seperti facebook dalam bentuk tulisan, karena karakter bahasa alay adalah menggabungkan berbagai karakter, angka alfabet, singkatan-singkatan serta penggunaan huruf kapital yang tidak beraturan. Bahasa ini dianggap sebagai media berekspresi yang khas dalam berkomunikasi di dunia maya (internet). Selanjutnya, bagaimanakah penggunaan bahasa alay di ruang publik berupa facebook. Tujuan penelitian ini mendeskripsikan penggunaan bahasa alay para remaja Pamekasan di facebook dalam konteks penggunaan singkatan, kata baru, dan kosa kata asing. Metode penelitian menggunakan deskriptif kualitatif karena data yang terkumpul berasal dari data kualitatif berupa data verbal bukan angka, yakni tindak tutur remaja pengguna facebook yang menulis status dan komentar. Berdasarkan hasil analisis data dapat disimpulkan bahwa penggunaan bahasa alay remaja Pamekasan di facebook pada penggunaan tindak tutur representatif cukup banyak, yaitu pada status atau komentar yang ditulis pada dinding facebook. Fungsi tindak tutur ini memberitahukan kepada orang lain mengenai sesuatu yang memiliki kesesuaian antara tuturan yang disampaikan dengan kenyataan yang terletak pada pihak penutur. Penggunaan 
bahasa alay remaja Pamekasan di facebook pada penggunaan tindak tutur direktif dapat dilihat pada status atau komentar yang ditulis dalam akun facebook, yaitu ketika tuturan pada akun facebook mengandung hal yang bersifat keinginan pihak penutur kepada orang lain untuk melakukan sesuatu. Penggunaan bahasa alay remaja Pamekasan pada penggunaan tindak tutur ekpresif dapat dilihat ketikan status atau komentar penutur di dinding facebook mengandung pernyataan yang menggambarkan apa yang penutur rasakan.

Correspondance address:

E-mail: hestykusumawati4@gmail.com (Hesty Kusumawati)

\section{Pendahuluan}

Secara umum dapat dikatakan bahwa bahasa adalah refleksi budaya bangsa. Penampilan bahasa Indonesia juga menunjukkan hal itu. Penampilan bahasa ditentukan oleh situasi masyarakat dan keadaan sosial tempat proses penggunaan bahasa itu berlangsung. Bahasa memegang peranan penting dalam komunikasi, melalui bahasa, kebudayaan dapat dibentuk dan dikembangkan. Tanpa bahasa, masyarakat tidak bisa berhubungan satu dengan yang lain. Fungsi bahasa bagi setiap orang ada empat, yaitu sebagai alat atau media komunikasi, ekspresi diri, integrasi atau adaptasi sosial, dan kontrol sosial (Keraf dalam Finoza, 2002).

Sikap bangsa Indonesia terhadap bahasa Indonesia cenderung ambivalen, sehingga terjadi dilematis. Artinya, di satu pihak kita menginginkan bahasa Indonesia menjadi bahasa modern, dan dapat mengikuti perkembangan zaman serta mampu merekam ilmu pengetahuan dan teknologi global, tetapi di pihak lain kita telah melunturkan identitas dan citra diri itu dengan lebih banyak mengapresiasi bahasa asing sebagai lambang kemodernan (Warsiman, 2010). Atas dasar itu, tidak heran jika para remaja masa kini lebih cenderung menggunakan bahasa asing atau bahasa gaul sebagai bagian dari hidupnya jika mereka tidak ingin disebut ketinggalan zaman.

Salah satu fenomena yang menarik adalah munculnya bahasa alay, bahasa alay merupakan salah satu variasi bahasa yang memiliki kelompok pemakai bahasa itu sendiri, bahasa alay dapat dengan mudah kita temui pada penulisan kalimat SMS atau jejaring sosial seperti facebook. Keberadaan bahasa alay oleh para remaja terutama sebagian remaja di Pamekasan yang memiliki hobi berselancar di dunia maya (internet), seperti facebook dapat dikenali dalam bentuk tulisan, karena karakter bahasa alay adalah menggabungkan berbagai karakter, angka alphabet, singkatan-singkatan serta penggunaan huruf kapital yang tidak beraturan. Bahasa ini dianggap sebagai media berekspresi, namun tanpa disadari lama kelamaan bahasa alay juga bisa menjadi bahasa khas dalam berkomunikasi di dunia maya (internet).

Berdasarkan latar belakang, bagaimanakah wujud penggunaan bahasa alay remaja Pamekasan di facebook? Penelitian ini bertujuan untuk mendeskripsikan penggunaan bahasa alay remaja Pamekasan di facebook, khususnya yang berkenaan dengan penggunaan singkatan, kata baru, dan kosa-kata asing. Pengumpulan data dilakukan dengan menggunakan observasi partisipan yang difokuskan pada subyek penelitian, yakni bahasa percakapan dalam facebook. Analisis data dilakukan dengan cara mendeskripsikan kembali data temuan sesuai dengan interpretasi sebelumnya.

\section{Metode}

Dalam penggunaan bahasa alay di ruang public ini menggunakan jenis deskriptif menggunakan pendekatan kualitatif. Deskriptif kualitatif akan mendeskripsikan dan memberikan keterangan yang jelas, objektif, sistematis dan kritis. Jenis penelitian yang digunakan adalah kepustakaan (library research) sehingga dalam penelitian ini berisikan beragam informasi kepustakaan. Sumber data penelitian yang diambil melalui buku-buku dan literature terkait. Teknik analisis data yang digunakan dalam penelitian ini menggunakan (content analysis) yaitu penelitian yang bersifat pembahasan 
mendalam terhadap isi suatu informasi tertulis atau tercetak. Dokumen-dokumen yang relevan di analisis isinya dengan sistematik dan objektif.

\section{Hasil dan Pembahasan}

\section{Penggunaan Bahasa Alay Remaja Pamekasan di Facebook}

Pada bagian ini akan dibahas data penggunaan bahasa alay remaja Pamekasan di facebook yang meliputi penggunaan tindak; (1) singkatan, (2) kata baru dan (3) kosa kata asing.

\section{a. Penggunaan Bahasa Alay Remaja Pamekasan di Facebook pada Penggunaan Singkatan}

Penggunaan singkatan pada bahasa alay remaja Pamekasan cukup banyak ditemukan, penggunaan singkatan pada penulisan bahasa alay digunakan untuk mengaktualisasikan diri dengan ekpresi pada tulisan. Singkatan tersebut dibentuk dengan tujuan memberikan nilai tambah pada katakata tersebut sehingga memberikan rasa yang berbeda dengan menarik perhatian daripada penggunaan singkatan pada bahasa Indonesia yang telah dianjurkan, walapun pada segi kebahasaan yang baku, hal ini menyalahi kaidah. Tindakan seperti ini menunjukkan sikap bahasa pada aspek kesetian bahasa yang rendah terhadap bahasa Indonesia (Dewantara, 2018a). Penggunaan singkatan pada kata-kata yang digunakan pada bahasa alay remaja Pamekasan dapat kita lihat sebagai berikut.

\section{Ririn Novalita: Bener $\mathbf{j g} . .$, hhe}

Kata juga di bentuk dengan singkatan jg, merupakan asal dari kata juga, namun singkatan tersebut tidak mengurangi makna dari kata asalnya, hal serupa juga dapat kita lihat pada kutipan berikut.

\section{Ngracak Fendi: dmrahi ta ma orng rmhx}

Kata yang mengalami singkatanisasi di atas berasal dari kata di marahi ta sama orang rumahnya? Bentuk singkatan tersebut dibentuk tanpa menggunakan aturan yang jelas, namun pada dasarnya masih bisa dipahami oleh lawan tuturan, selain itu kreatifitas dalam membuat singkatan pada kata juga dapat kita lihat di bawah ini.

\section{Ngracak Fendi: trus skrng gmn}

Singkatan di atas berasal dari kata terus sekarang bagaimana, singkatan di atas dibentuk dengan cara menghilangkan sebagian besar huruf vokal dan tetap mempertahankan huruf konsonan, huruf yang tetap digunakan untuk menghindari salah tafsir pembaca tulisan tersebut. Berbeda dengan data berikut.

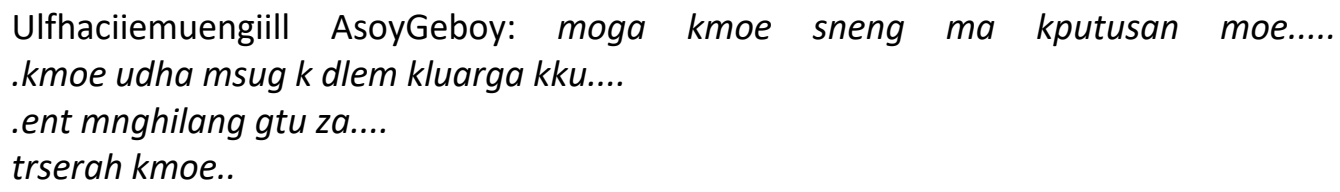

Ulfhaciiemuengiill AsoyGeboy: moga kmoe sneng ma kputusan moe..... .kmoe udha msug $k$ dlem kluarga kku....

.ent mnghilang gtu za....

trserah kmoe..

Penggunaan singkatan di atas dilakukan dengan cara menghilangkan sebagian vokal, atau memodifikasi kata seperti kata kamu menjadi kmoe, masuk menjadi msug, dalam menjadi dlem, hal tersebut semata-mata hanya untuk menarik perhatian lawan tutur atau pembaca tulisan tersebut.

\section{b. Penggunaan Bahasa Alay Remaja Pamekasan di Facebook pada Kata Baru}

Penggunaan kata baru pada bahasa alay remaja Pamekasan di facebook merupakan kata-kata yang banyak diadopsi sebagai bahasa yang umum dalam komunitas mereka, sehingga kata-kata ini 
sulit dipahami oleh orang-orang di luar komunitas mereka. Kata baru yang terdapat pada facebook remaja Pamekasan dapat kita lihat pada kutipan berikut

Windy Lupzz F Zlalu: buK yuliati.* ngampull laaahhhh

jdie Tattutt aqUeee

hiiiiii seReemm loK Igie ngampuuulll :/

ngumpet De kmar ja Dech gk Ush Kluar.dri pda Deomeliiinn...

Pada data di atas terdapat kata baru yaitu pada kata tattutt, kata tattutt berasal dari kata takut, namun dimodifikasi sedemikian rupa untuk menimbulkan rasa yang lebih menarik daripada kata asalnya. Hal serupa juga dapat kita lihat pada kutipan di bawah ini.

Ulfhaciiemuengiill AsoyGeboy: akku ndag tw pek kpan kku kek gnie.....

\section{Sodokur}

huuufttt.....

capeg akkkuu

Pada data di atas terdapat kata sodokur yang berpadanan dengan kata saudara, kata-kata ini memiliki nilai tambah yaitu menarik daripada kata yang digunakan biasanya, hal inilah yang membuat istilahistilah semacam ini menjadi trend dalam berbahasa anak remaja, berbeda dengan data di bawah ini, yaitu pada kata yang memiliki makna lebih menarik, sebagai berikut.

Firmand'z Doank: Mungkn smpai kmu menutup

kedua mata kmu pola, ka nada aku si Brownies.

Kata Brownies merupakan kata baru yang memiliki makna Brondong Manis atau anak muda belia yang tampan atau cantik. Kata brownies mengacu pada seseorang yang dianggap lebih muda dan memiliki ketampanan atau kecantikan yang akan dijadikan pasangan untuk senang-senang saja, sehingga kata brownies dapat berkonotasi negatif. Ada kalanya kata baru hanya digunakan untuk memberi rasa senang seperti pada kutipan berikut.

Syam Adinata: Siang bolong gene $k o^{\prime}$ da yg skt ht....

Sini ku obati, pasti rebes

Kata baru rebes merupakan kata yang berasal dari kata beres, kata rebes ini dianggap lebih menarik daripada kata beres karena dapat menimbulkan kesan bahasa yang digunakan merupakan bahasa pergaulan masa kini atau tidak ketinggalan jaman. Selain itu, kata baru juga dapat berfungsi untuk memberikan kesan yang lebih mendalam, seperti pada data berikut.

Dayat Ling Lung hahahaha :) ydah bsok tak hibur d sklh :D male tak galau tok benh :D

Cembokur ma spa?

Pada data di atas terdapat kata Cembokur, kata cembokur berpadanan dengan kata cemburu pada kosa kata bahasa Indonesia, namun kata cembokur dapat memberikan kesan tersembunyi karena lawan tutur masih memerlukan waktu untuk memberikan arti pada kata baru tersebut.

\section{c. Penggunaan Bahasa Alay Remaja Pamekasan di Facebook pada Kosa Kata Asing}

Penggunaan kosa kata asing pada bahasa alay remaja pamekasan di facebook banyak ditemukan pada status atau komentar. Penggunaan kosa kata asing ini bertujuan untuk memberikan nilai rasa agar dianggap lebih keren jika kosa kata tersebut berasal dari bahasa luar negeri, dan 
menambah nilai rasa keakraban jika menggunakan kosakata asing yang berasal dari bahasa daerah, seperti yang dapat kita lihat berikut.

Ririn Novalita: Capek..capek..capek..capek....butuh refress pi gak da wktu...jadwal padet mulu kaya' artis...hhe

Pada data di atas terdapat kata refress penggunaan kosa kata asing pada status facebook biasanya digunakan untuk meningkatkan prestise penutur sehingga dianggap anak yang modern dan tidak kampungan, sebaliknya jika menggunakan kosa kata asing yang berasal dari bahasa daerah, biasanya digunakan untuk membentuk suasana yang lebih akrab, seperti pada kutipan berikut ini.

Windy Lupzz F Zlalu: buK yuliati.* ngampull laaahhhh

jdie Tattutt aqUeee

hiiiiii seReemm loK Igie ngampuuulll :/

ngumpet De kmar ja Dech gk Ush Kluar.dri pda Deomeliiinn...

Pada data di atas, terdapat kata yang berasal dari kosa kata bahasa daerah yaitu ngampuuulll biasanya kosa kata tersebut digunakan untuk menunjukkan keakraban dengan lawan tutur yang sebelumnya memang sudah memiliki hubungan pertemanan yang akrab.

\title{
GaphlezPunnah Pangerankodok Hahaha :D
}

... Ben lakarr la tokang lawak gebey obat galau pak yatt :p

Pada data di atas, terdapat kata yang berasal dari kosa kata bahasa daerah yaitu Ben lakarr la tokang lawak gebey biasanya kosa kata tersebut digunakan untuk meningkatkan keakraban dengan lawan tutur. Selain itu, terkadang penggunaan kosa kata asing terutama kosa-kata yang berasal dari bahasa daerah juga digunakan untuk memberi penekanan dan nilai rasa yang lebih mantap, sehingga kata-kata yang digunakan akan lebih bermakna jika dilihat oleh lawan tutur seperti kutipan di bawah ini.

\author{
Lia Pasukan ArmadAshter: \\ kamu kalau senyum biasa aja dong...!!! \\ masa membekas di hati gk ilang-illangg ??? \\ \#Always Asarongan
}

Hasil penelusuran ini menunjukkan bahwa penggunaan bahasa alay di ruang publik dengan banyak tujuan. Tujuan-tujuan tersebut menunjukkan semakin menipisnya sikap bahasa positif terhadap bahasa Indonesia. Karena itu, berbagai cara perlu dilakukan agar sikap bahasa positif berupa kesetiaan, kebanggaan, dan kesadaran akan norma bahasa dapat diwujudkan. Sebagai contoh melalui insersi sikap bahasa sebagaimana yang pernah dicoba Dewantara (2018a). Pentingnya penanaman sikap bahasa positif terhadap bahasa Indonesia didasarkan pada fakta bahasa adalah pengikat nasionalisme dalam bingkai kebhinekaan (Dewantara 2018b).

\section{Simpulan}

Berdasarkan hasil pembahasan, maka penggunaan bahasa alay di ruang publik oleh remaja Pamekasan di facebook dapat disimpulkan sebagai berikut.

1. Penggunaan bahasa alay remaja Pamekasan di facebook pada penggunaan singkatan. Penggunaan singkatan pada bahasa alay remaja Pamekasan cukup banyak ditemukan singkatan tersebut dibentuk dengan tujuan memberikan nilai tambah pada kata-kata tersebut sehingga memberikan rasa yang berbeda dengan menarik perhatian. 
2. Penggunaan kata baru pada bahasa alay remaja Pamekasan di facebook merupakan kata-kata yang banyak diadopsi sebagai bahasa yang umum dalam komunitas mereka, sehingga kata-kata ini sulit dipahami oleh orang-orang di luar komunitas mereka.

3. Penggunaan kosa kata asing bertujuan untuk memberikan nilai rasa agar dianggap lebih keren jika kosa kata tersebut berasal dari bahasa luar negeri, dan menambah nilai rasa keakraban jika menggunakan kosakata asing yang berasal dari bahasa daerah

\section{Daftar Pustaka}

Chaer, abdul. 2007. Linguistik Umum. Jakarta: Rineka Cipta

Dewantara I Putu Mas. 2018a. Insersi Nilai Sikap Bahasa dalam Pembelajaran: Refleksi Analisis

Kebutuhan Belajar. Seminar Nasional Bahasa, Sastra, dan Pengajarannya, [S.I.], v. 5, p. 254259, sep. 2018. ISSN 2623-288X. Available at:

$<$ https://eproceeding.undiksha.ac.id/index.php/semnasbasindo/article/view/1287>

Dewantara, IPM. 2018b. Text Attributed with Language Attitude in Indonesian Language Instruction as The Efforts to Knit Nationalism in a Frame of Diversity. Global Conference on Teaching, Assessment, and Learning in Education (GC-TALE 2017) Vol 42, 2018. https://doi.org/10.1051/shsconf/20184200026

Finoza, Laminuddin. 2002. Komposisi bahasa Indonesia untuk Mahasiswa Non Jurusan Bahasa. Jakarta: Diksi Insan Mulia

Hartono. 1992. Kamus Praktis Bahasa Indonesia. Jakarta: Rineke Cipta.

Kridalaksana, Harimurti. 2008. Kamus Linguistik (edisi keempat). Jakarta: Gramedia.

Madcom. 2011. Berinternet dengan Facebook dan Twitter Untuk Pemula. Madiun: ASDI

Nababan, P.W.J. 1984. Sosiolinguistik. Jakarta: PT. Gramedia.

Shinta, Ayu. Hanbook Bahasa Alay. Yogjakarta: Araska

Sumarsono. 2009. Sosiolinguistik. Yogjakarta. Pustaka Ilmu

Tarigan, Henry Guntur. 2009. Pengajaran pragmatik. Bandung: Jakarta

Warsiman. 2010. Bahasa Indonesia Teori dan Aplikasi. Surabaya: Unesa Press

Wijana, Dewa Putu. 2006. Sosiolinguistik. Yogjakarta: Pustaka Pelajar

Brown, Gillian dan George Yule. 1983. Discourse Analysis. Cambridge: Cambrdge University Press. 